\title{
The dynamics of the actin cytoskeleton during sporogenesis in Psilotum nudum L.
}

\author{
Dorota Tchórzewska • Józef Bednara
}

Received: 24 March 2010 /Accepted: 20 May 2010/Published online: 11 June 2010

(C) The Author(s) 2010. This article is published with open access at Springerlink.com

\begin{abstract}
The actin cytoskeleton (microfilaments, MFs) accompanies the tubulin cytoskeleton (microtubules) during the meiotic division of the cell, but knowledge about the scope of their physiological competence and cooperation is insufficient. To cast more light on this issue, we analysed the F-actin distribution during the meiotic division of the Psilotum nudum sporocytes. Unfixed sporangia of P. nudum were stained with rhodamine-phalloidin and 4',6-diamidino-2-phenylindole dihydrochloride, and we monitored the changes in the actin cytoskeleton and nuclear chromatin throughout sporogenesis. We observed that the actin cytoskeleton in meiotically dividing cells is not only part of the kariokinetic spindle and phragmoplast but it also forms a well-developed network in the cytoplasm present in all phases of meiosis. Moreover, in telophase I F-actin filaments formed short-lived phragmoplast, which was adjacent to the plasma membrane, exactly at the site of future cell wall formation. Additionally, the meiocytes were pre-treated with cytochalasin-B at a concentration that causes damage to the MFs. This facilitated observation of the effect of selective MFs damage on the course of meiosis and sporogenesis of $P$. nudum. Changes were observed that occurred in the cytochalasin-treated cells: the daughter nuclei were located abnormally close to each other, there was no formation of the equatorial plate of organelles and, consequently, meiosis did not occur normally. It seems possible that, if the actin cytoskeleton only is damaged,
\end{abstract}

Handling Editor: Adrienne Hardham

D. Tchórzewska $(\bowtie) \cdot J$. Bednara

Department of Plant Anatomy and Cytology,

Maria Curie-Skłodowska University,

Akademicka 19,

20-033 Lublin, Poland

e-mail: dorota.tchorzewska@poczta.umcs.lublin.pl regular cytokinesis will not occur and, hence, no viable spores will be produced.

Keywords F-actin · Meiosis · Rhodamine-phalloidin . Cytochalasin-B $\cdot$ Psilotum nudum

\section{Introduction}

The cytoskeleton is a dynamic structure changing during division, growth and development of the cell. Microtubules (MTs) and microfilaments (MFs) are the main components of the cytoskeleton in plant cells and they participate in numerous processes occurring inside interphasal and dividing cells. They are responsible, among others, for the control of the cell shape and growth and development of the plant cell wall; they also organise the cytoplasm (cytomorphogenesis), transport cellular structures, bring about cell motility and mitotic and meiotic divisions (Hepler 1981; Gunning 1981; Gunning and Hardham 1982; Dustin 1984; Lloyd and Seagull 1985; Bershadsky and Vasiliev 1988; Fosket 1989; Hepler et al. 1993; Zhao et al. 1999; Battey et al. 1999; Van et al. 2002).

Both in sporogenesis and in microsporogenesis in meiotic cells, MTs form a radial microtubule system, meiotic spindles in division I and II of the nucleus and a phragmoplast, which arises in telophase I and II (Brown and Lemmon 1982a, 1987a, b, 1988b, 1991b, 1996, 1998, 2001a, b, 2004, 2009; Bednara et al. 1995; Bohdanowicz et al. 2005). In some species, additional Mt configurations were observed: those related to the plastid division in monoplastid species (Brown and Lemmon 1982b, 1985) with the characteristic location of cell organelles in Lavatera thuringiaca microsporocytes (Tchórzewska et al. 2008), or those which occur in some leafy liverworts (Brown and Lemmon 2009). 
The actin cytoskeleton is associated with configurations of the microtubules during meiotic division, which has been described in a few plant species, e.g. S. melongena (Traas et al. 1989), Gasteria verrucosa (van Lammeren et al. 1989; Bednara et al. 1990), orchids (Brown and Lemmon 1991c), Zea mays (Staiger and Cande 1991, 1993), and Solanum sp. (Genualdo et al. 1998). Although the MFs are present together with the MTs in the successive stages of the cell life cycle, there are differences in the spatial organisation of the actin and tubulin cytoskeleton, e.g. MFs form a cytoplasmic network present throughout all the stages of meiosis, which has been reported from, e.g. S. melongena (Traas et al. 1989) and Magnolia soulangeana (Dinis and Mesquita 1993).

Up to date, there are only few reports about F-actin organisation in plant cells, especially in meiotically dividing plant cells. Furthermore, although MTs and MFs are present in the cytoplasm, often in close vicinity, there is no sufficient knowledge about the scope of their physiological competence and cooperation. To provide more information about that, in this paper, we analysed F-actin distribution during the meiotic division of the Psilotum nudum sporocytes. $P$. nudum represents an interesting plant from evolutionary point of view, regarded by some to living relicts of the earliest vascular plants (Rothwell 1999). This species is a homosporous fern from a small subdivision of telome plants-Psilotophytina (Bierhorst 1971; Renzaglia et al. 2001). Previously, the Psilotaceae has been regarded as a separate and early divergent Tracheophyta lineage (Wagner 1977). However, Bierhorst (1977) and White (1977) considered Psilotum and Tmesipteris as filicopsid ferns. Molecular phylogenetic analyses have repeatedly supported a sister relationship between Psilotaceae and Ophioglossaceae and they still provide important insight for understanding of the development and evolution of seed plants (Manhart 1994, 1995; Hasebe et al. 1995; Pahnke et al. 1996; Wolf 1997; Wolf et al. 1998; Nickrent et al. 2000; Pryer et al. 1995, 2001; Renzaglia et al. 2007).

In our research, attention was paid to the dynamic changes in the MFs during the consecutive meiotic stages. We examined meiocytes pre-treated with cytochalasin-B at an MF-damaging concentration. Thus, we were able to observe the effect of selective MFs damage in the course of meiosis and sporogenesis of $P$. nudum.

\section{Material and methods}

Plant material

Differently sized sporangia of $P$. nudum plants were collected from the greenhouse at the Department of Plant Anatomy and Cytology, Maria Curie Skłodowska University in Lublin, Poland.
Fluorescence microscopy

The unfixed sporangia of $P$. nudum in different stages of sporogenesis were squashed in the dark, in $10^{-6} \mathrm{M}$ rhodamine-phalloidin (Sigma) in MSB buffer pH 6.9 to visualised the MFs (Baluska and Barlow 1993). In order to stain DNA in the nuclei and organelles, $0.1 \mathrm{mg} / \mathrm{ml} \mathrm{4^{ \prime } , 6 -}$ diamidino-2-phenylindole dihydrochloride (DAPI) in MSB was added to the slides. Then, after $10 \mathrm{~min}$ the slides were rinsed with $0.05 \mathrm{M}$ mannitol solution in MSB buffer. The slides were observed under a fluorescence microscope (Nikon Optiphot II). Images of sporocytes and spores were recorded on Kodak TMAX-400 film.

Treatment with cytochalasin-B

Differently sized sporangia of $P$. nudum were treated with cytochalasin-B (10 $\mu \mathrm{g} / \mathrm{ml}$ of the water solution) for $48 \mathrm{~h}$ in a moist chamber. Afterwards, the sporangia were prepared for observation under the fluorescence microscope as described above.

\section{Electron microscopy}

For transmission electron microscopy the sporangia were fixed in $2.5 \%$ paraformaldehyde and $2.5 \%$ glutaraldehyde in $0.1 \mathrm{M}$ phosphate buffer ( $\mathrm{pH}$ 6.9) for $24 \mathrm{~h}$ at room temperature. The specimens were washed three times in phosphate buffer and postfixed in $2 \%$ osmium tetroxide. Afterwards, they were dehydrated in a graded ethanol series and embedded in London Resin White Medium (Sigma). Ultrathin sections $(60 \mathrm{~nm})$ were stained with uranyl acetate $(5 \mathrm{~min})$ and lead citrate (10 min). The sections were observed with a JEM 100B transmission electron microscope.

\section{Results}

Double-staining with rhodamine-phalloidin and DAPI of $P$. nudum meiotically dividing cells facilitated parallel tracing of the changes in microfilament configurations and a precise determination of the sporogenesis stage on the basis of the nucleus behaviour. During early prophase I in $P$. nudum meiocytes, microfilaments were visible in a form of long and relatively thick strands located in close vicinity of the cell wall and as a delicate network pervading the cytoplasm (1a of Fig. 1). At that time, chromatin remodelling, typical of the meiotic division, commenced in the nucleus (1b of Fig. 1). During the leptotene stage, the long F-actin strands located at the cell wall underwent depolymerization, and a well-formed network was visible ( 2 a of Fig. 1). This network surrounds the cell organelles, whose nucleoids are visible in $2 \mathrm{~b}$ of Fig. 1 . At this stage, the 

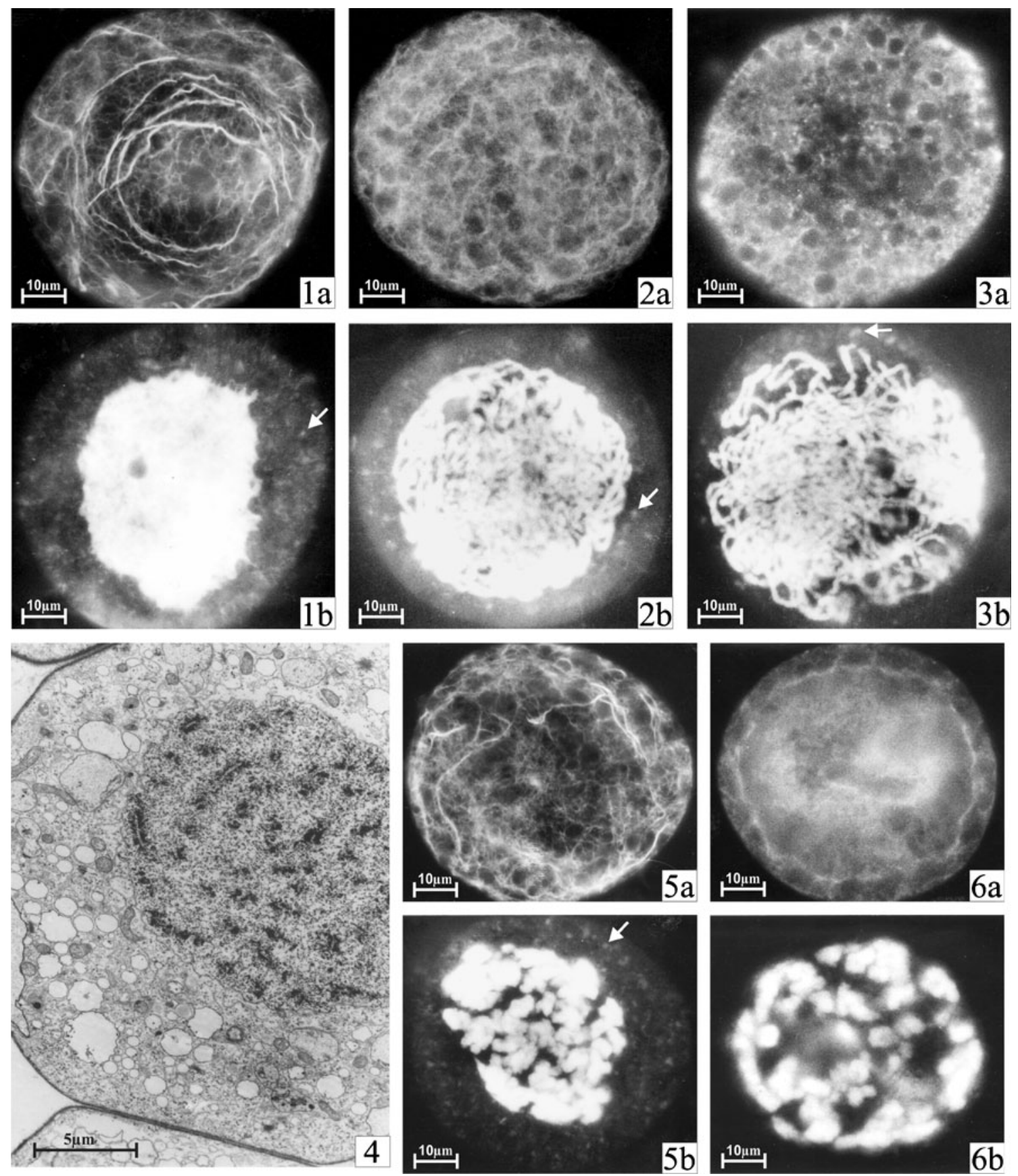

Fig. 11 Sporocytes of $P$. nudum during prophase I. MF stained with rhodamine-phalloidin. Nuclear and organellar DNA stained with DAPI. $a, b$ Early prophase I. $a \mathrm{MF}$ in the form of long strands located close to the cell wall and a delicate network pervading the cytoplasm. $b$ An early prophase nucleus and nucleoids of cell organelles dispersed in the cytoplasm (arrow). 2 Sporocytes of P. nudum during prophase I. MF stained with rhodamine-phalloidin. Nuclear and organellar DNA stained with DAPI. $a, b$ Early leptotene. $a$ MFs form a dense network around the cell organelles dispersed in the cytoplasm. $b$ Thin, long, tangled nuclear chromatin threads (arrow-nucleoids of cell organelles). 3 Sporocytes of $P$. nudum during prophase I. MF stained with rhodaminephalloidin. Nuclear and organellar DNA stained with DAPI. $a, b$ Middle leptotene. $a$ MFs form a dense network around the cell organelles dispersed in the cytoplasm. $b$ Thin, long, tangled nuclear chromatin threads (arrow - nucleoids of cell organelles). 4 Sporocytes of $P$. nudum during prophase I (zygotene). Spiralized chromosomes are visible in the nucleus and organelles (mitochondria, plastids and vacuoles) are evenly dispersed in the cytoplasm (TEM). 5 Sporocytes of $P$. nudum during prophase I. MF stained with rhodamine-phalloidin. Nuclear and organellar DNA stained with DAPI. $a, b$ Pachytene. $a$ MFs in the form of a three-dimensional network around the cell organelles and long strands directly under the plasma membrane (arrow). $b$ Visible bivalents of homologous chromosomes and nucleoids of the cell organelles dispersed in the cytoplasm (arrow). 6 Sporocytes of $P$. nudum during prophase I. MF stained with rhodamine-phalloidin. Nuclear and organellar DNA stained with DAPI. $a, b$ Diplotene. $a$ MFs tightly surround the chromosomal bivalents thus forming the perinuclear concentration. $b$ Visible bivalents of homologous chromosomes 
nuclear chromatin condensation proceeded and thicker chromatin threads are formed (2b of Fig. 1). During late leptotene, F-actin was discernible mainly at the cell organelles evenly dispersed in the cytoplasm ( $3 \mathrm{a}, \mathrm{b}$ - arrow of Fig. 1). Nuclear chromatin formed distinct, long, thicker and more loosely arranged threads ( $3 b$ of Fig. 1).
Since the rhodamine-phalloidin staining was performed in toto on crushed preparations, the distribution of the organelles was additionally analysed in ultrathin meiocyte sections under the electron microscope. Figure 1 (4) presents a meiotic cell in the prophase I zygotene stage. The nucleus with the persisting nuclear envelope contained
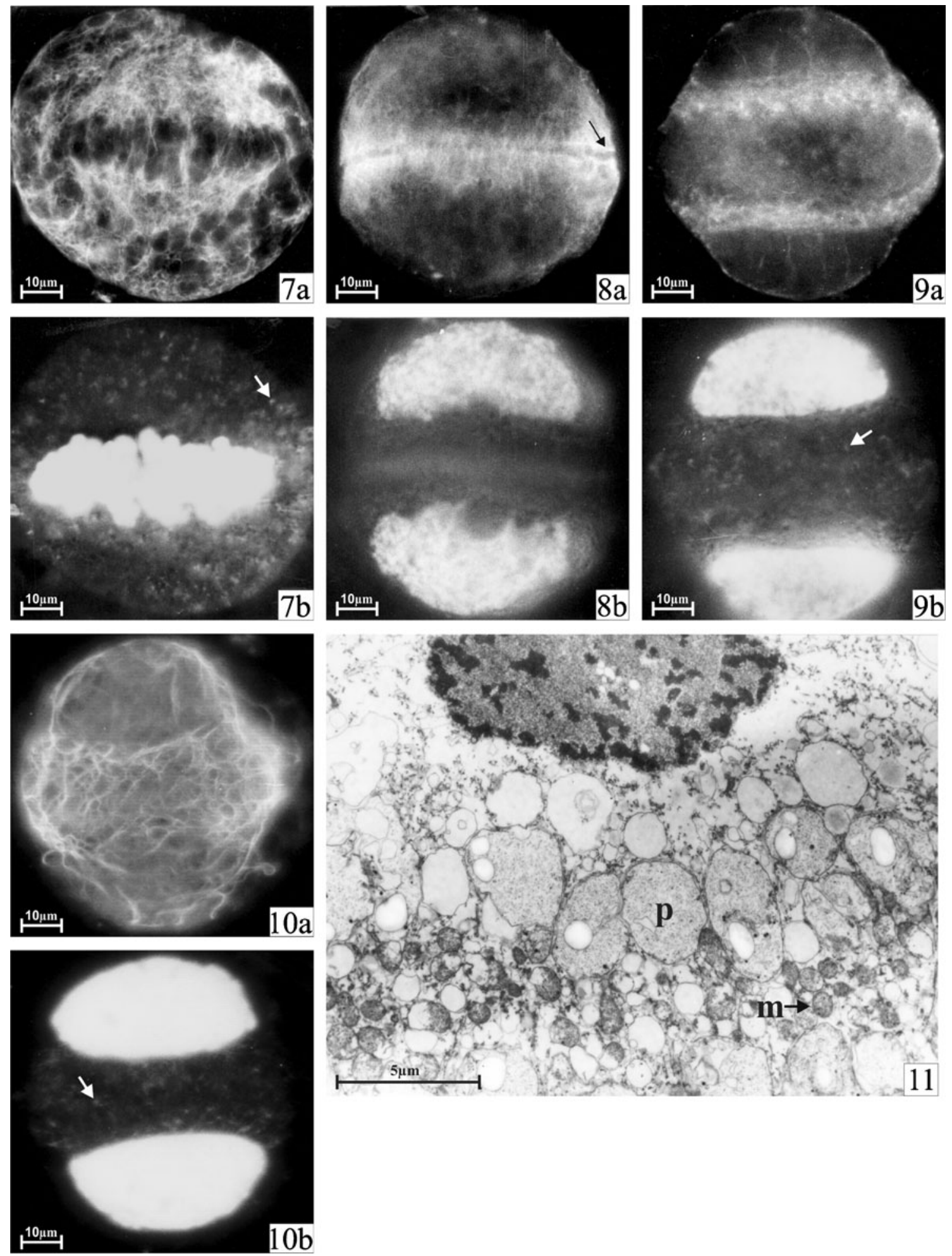
slightly spiralized homologous chromosomes paired by synaptomenal complexes. The cytoplasmic cell organelles, such as mitochondria, plastids, dictiosomes and vacuoles, were evenly dispersed in the cytoplasm.

In pachytene, a successive prophase I stage, F-actin formed a three-dimensional network surrounding the cell organelles, whose nucleoids are visible in $5 \mathrm{~b}$ of Fig. 1; also, long microfilament strands were visible just under the plasma membrane (5a of Fig. 1). Progressing spiralization of the nuclear chromatin was visible in the DAPI staining, and the nucleoids of the cell organelles were present in the whole cytoplasm (5b of Fig. 1). During late prophase I (diplotene), the microfilaments tightly surrounded the chromosomal bivalents thus forming a perinuclear concentration. At this stage, the number of cytoplasmic microfilaments in the rest of the cytoplasm was observed (6a of Fig. 1). The cells in the diplotene stage displayed strongly spiralized short bivalents of the homologous chromosomes (6b of Fig. 1).

In metaphase I meiocytes, the microfilaments were present in the whole cytoplasm and they additionally formed the kariokinetic spindle (7a of Fig. 2). The chromosomes formed a classic metaphase plate at that time ( $7 b$ of Fig. 2). During early telophase I, the actin filaments in the phragmoplast were oriented perpendicularly to the equatorial plane of the meiocyte at the border of daughter nuclei reaching the cell margin. The MFs present on the cell margin formed a characteristic short-lived phragmoplast located exactly at the future cell wall (8a of Fig. 2). In the study cell, it is possible to precisely determine the early telophase I stage on the basis of the uneven inner surfaces of the daughter nuclei ( $8 b$ of Fig. 2). In late telophase I, the

Fig. 27 Sporocytes of $P$. nudum. MF stained with rhodaminephalloidin. Nuclear and organellar DNA stained with DAPI. $a, b$ Metaphase I. $a$ MFs are part of the kariokinetic spindle and they are found throughout the cytoplasm. $b$ The chromosomes form a metaphase plate (arrow - nucleoids of cell organelles). 8 Sporocytes of $P$. nudum. MF stained with rhodamine-phalloidin. Nuclear and organellar DNA stained with DAPI. $a, b$ Early telophase I. $a$ MFs form the phragmoplast, which is oriented perpendicularly to the daughter nuclei. It is arranged in a characteristic ring (arrow) located directly at the cell wall in the cell equatorial plane. $b$ Visible daughter nuclei. 9 Sporocytes of $P$. nudum. MF stained with rhodaminephalloidin. Nuclear and organellar DNA stained with DAPI, telophase I. $a, b$ The distal optical plane. $a$ MFs are found mainly at the daughter nuclei. $b$ Visible daughter nuclei at the opposite cell poles and cell organelles between the nuclei (arrow). 10 Sporocytes of P. nudum. MF stained with rhodamine-phalloidin. Nuclear and organellar DNA stained with DAPI, telophase I. $a, b$ The proximal optical plane. $a$ Net-like MFs surround the daughter nuclei and the cell organelles. $b$ Nucleoids of the cell organelles visible between the two daughter nuclei (arrow). 11 Sporocytes of P. nudum. Telophase in TEM. Visible cell nuclei and the three-layered plate of cell organelles: an internal mitochondrial layer and two externally located plastid layers; $p$ plastids, $m$ mitochondria characteristic actin phragmoplast disappeared and when the distal optical plane was focused on, the microfilaments were visible mainly at the daughter nuclei (9a of Fig. 2). In such cells, the daughter nuclei were found at the opposite poles; their surface was smooth and the cell organelles were located between the nuclei ( $9 \mathrm{~b}$ of Fig. 2). In telophase cells, when the proximal optical plane was focused on, we observed net-like microfilaments surrounding the daughter nuclei and the cell organelles (10a of Fig. 2). In such cells, a dense array of nucleoids of the cell organelles was visible between the two daughter nuclei (10b of Fig. 2). The electron microscope images of telophase I meiotic cells show cell nuclei and the equatorial plate of organelles that separates them. The organelles are arranged in a threelayered plate with an internal mitochondrial layer and two externally located plastid layers which were lying in closer proximity to the cell nuclei. Total absence of plastids and mitochondria beyond the equatorial plane, e.g. at the cell poles, should be emphasised (11 of Fig. 2).

During metaphase II, the kariokinetic spindles in meiocytes are arranged perpendicularly to each other. The microfilaments in such cells were part of the kariokinetic spindles and form a dense network in the cytoplasm (12a of Fig. 3). The chromosomes which formed two metaphase plates were arrayed in different planes, almost perpendicularly to each other (12b of Fig. 3). In the telophase II meiocytes, the microfilaments formed narrow phragmoplasts visible at the site of the future cell walls. The phragmoplasts were placed beneath the plasma membrane and were mainly composed of parallel microfilament strands (13a and 14 of Fig. 3). At this stage, four daughter nuclei were visible after DAPI staining (13b of Fig. 3). The telophase II meiocytes observed under the electron microscope displayed four daughter nuclei separated by the equatorial plates of organelles. In 15 of Fig. 3, two out of the four daughter nuclei as well as mitochondria adjacent to the site of the future cell wall are visible. The plastids were located outside the mitochondria and closer to the cell nuclei. After cytokinesis and formation of the spore tetrad, the actin cytoskeleton was formed by long microfilament strands in the cortical cytoplasm, which were perpendicularly oriented to the cell surface, while the MFs in the inner zone formed a three-dimensional net (16a of Fig. 3). At that time, the spores contained cell organelles homogeneously dispersed in the cytoplasm (16b of Fig. 3).

Treatment of $P$. nudum meiocytes with cytochalasin-B during sporogenesis resulted in damage to the actin cytoskeleton which involved both inhibition of polymerisation and partial degradation of the existing microfilaments. In prophase meiocytes treated with cytochalasin-B, F-actin was present in the form of short fragments arrayed in a characteristic network in the cytoplasm (17a of Fig. 4). The actin cytoskeleton had this configuration, for instance, 

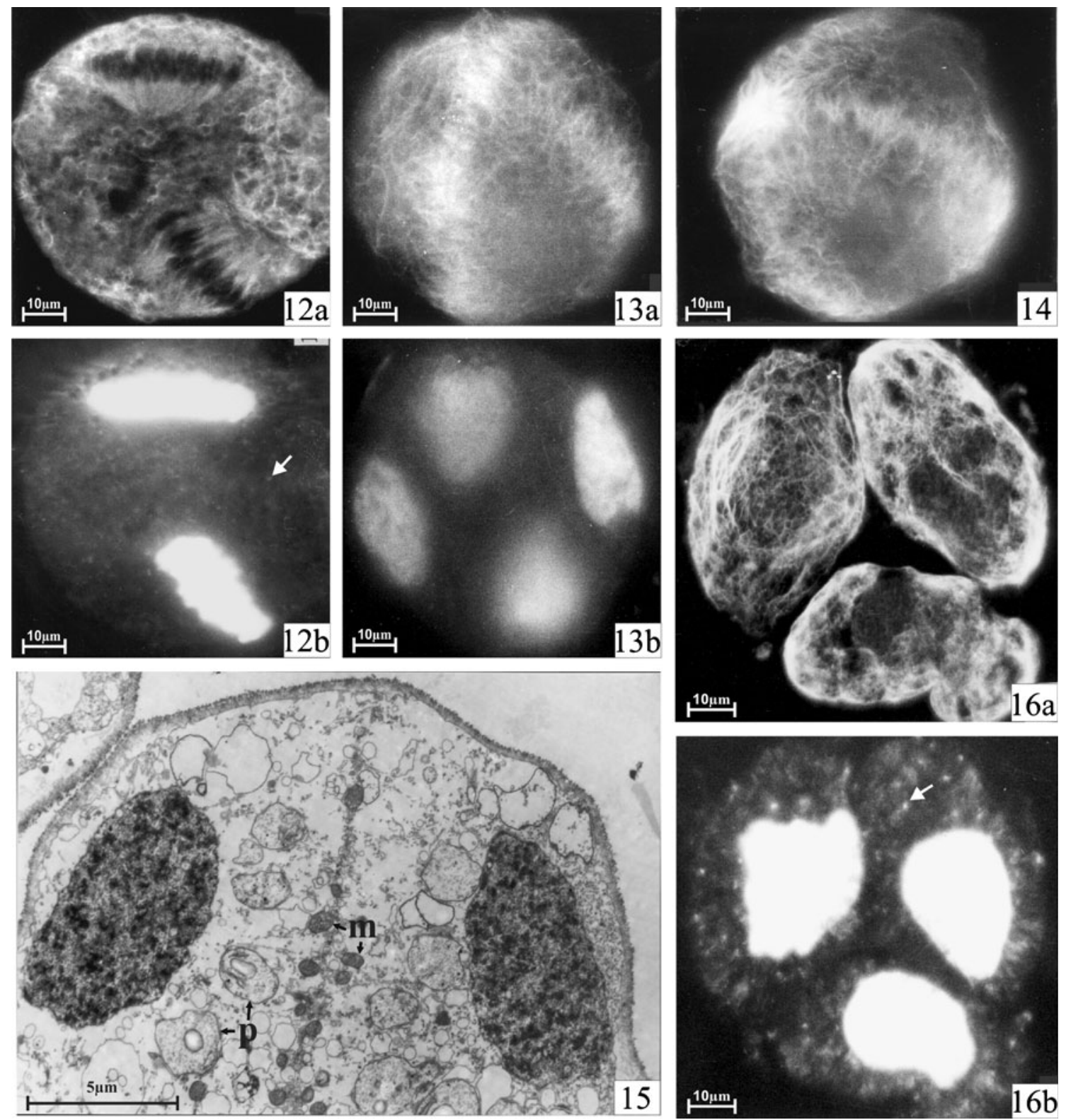

Fig. 312 Sporocytes of $P$. nudum. MF stained with rhodaminephalloidin. Nuclear and organellar DNA stained with DAPI, Metaphase II. $a$ MFs are part of the kariokinetic spindles and surround the cell organelles in the whole cytoplasm. $b$ Chromosomes form metaphase plates (arrow - nucleoids of cell organelles). 13 Sporocytes of $P$. nudum. MF stained with rhodamine-phalloidin. Nuclear and organellar DNA stained with DAPI, telophase II. $a$ MFs form phragmoplasts visible as two rings located between the daughter nuclei. $b$ Visible four daughter nuclei. 14 Sporocytes of $P$. nudum. MF stained with rhodamine-phalloidin. Nuclear and organellar DNA stained with DAPI, telophase II. MFs form phragmoplasts visible as two rings located between the daughter nuclei. 15 Sporocytes of $P$. nudum. Telophase II in TEM. Two out of the four daughter nuclei are visible, the mitochondria are found at the site of the future cell wall, the plastids are found closer to the nuclei (TEM); $p$ plastids, $m$ mitochondria. 16 Sporocytes of $P$. nudum. MF stained with rhodamine-phalloidin. Nuclear and organellar DNA stained with DAPI. $a, b$ A tetrad of spores. $a$ MFs form a cortical and a central cytoplasmic network. $b$ Visible oval nuclei and cell organelles dispersed in the cytoplasm (arrow) in the late prophase I, where chromatin in the cell nuclei was strongly condensed and formed bivalents $(17 \mathrm{~b}$ of Fig. 4). The meiotic cells treated with cytochalasin at the initial stage of telophase I displayed a bundle-shaped actin cytoskeleton; however, the short bundles did not form a typical phragmoplast. Slightly longer microfilament frag- ments were only visible at the border of the nuclei (18a of Fig. 4). In the DAPI-stained cells at this stage, two kidneyshaped nuclei located at the two cell poles were seen $(18 \mathrm{~b}$ of Fig. 4). Meiocytes treated with cytochalasin-B at a later stage, e.g. at the beginning of telophase II, had short, crossed microfilaments that were non-directionally distrib- 

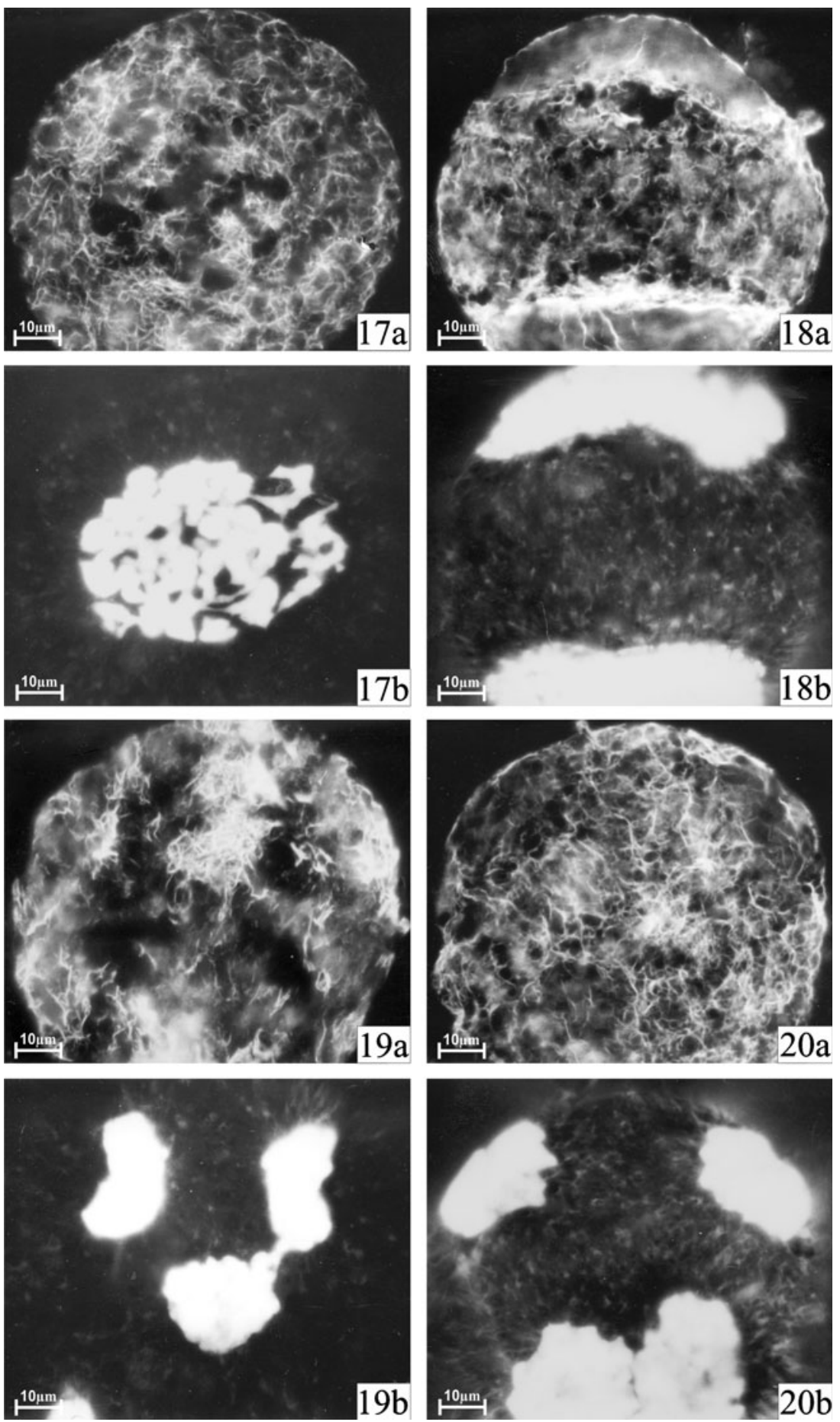

Fig. 417 Sporocytes of $P$. nudum treated with cytochalasin-B. MFs stained with rhodamine-phalloidin. Nuclear and organellar DNA stained with DAPI. $a, b$ Prophase I. $a$ F-actin has a form of only short fragments dispersed in the cytoplasm. $b$ The nuclear chromatin is highly condensed. 18 Sporocytes of $P$. nudum treated with cytochalasin-B. MFs stained with rhodamine-phalloidin. Nuclear and organellar DNA stained with DAPI. $a, b$ telophase I. $a$ MFs as short bundles; slightly longer fragments are visible only at the borders of the nuclei. $b$ Two lens-shaped nuclei are visible at the two cell poles. 19 Sporocytes of $P$. nudum treated with cytochalasin-B. MFs stained with rhodamine-phalloidin. Nuclear and organellar DNA stained with DAPI. $a, b$ Early telophase II. $a$ Short branching fragments of MFs arranged in a non-directional mode can be seen in the cytoplasm. $b$ Three out of the four daughter nuclei and cell organelles are dispersed in the cytoplasm. 20 Sporocytes of $P$. nudum treated with cytochalasin-B. MFs stained with rhodamine-phalloidin. Nuclear and organellar DNA stained with DAPI. $a, b$ Telophase II. $a$ Shorter and less regularly arranged MFs form a phragmoplast-like network. $b$ Four nuclei and nucleoids of the cell organelles dispersed in the cytoplasm are visible 
uted in the cytoplasm and did not resemble a phragmoplast (19a of Fig. 4). After DAPI staining, newly formed cell nuclei and nucleoids of the organelles were evenly dispersed both in the proximal and peripheral cytoplasm (19b of Fig. 4). In some telophase cells, the microfilaments formed a network that was slightly similar to a phragmoplast, but the filament bundles were distinctly shorter and less regularly arrayed than in the control, i.e. they did not display the typical parallel filament arrangement (20a of Fig. 4). In such cells, DAPI staining showed four nuclei and cell organelles which were chaotically dispersed in the cytoplasm and did not form equatorial plates (20b of Fig. 4).

\section{Discussion}

Actin microfilaments participate in many fundamental processes in plant growth and development, but their exact function is still obscure. Our study was focused on $P$. nudum meiocytes in vivo stained with rhodaminephalloidin, which facilitated examination of actin filaments during sporogenesis with simultaneous cytokinesis. The results showed that microfilaments exist at all stages of meiosis. They were present in four basic configurations: the cortical network, the central cytoplasmic network, the kariokinetic spindle and the phragmoplast. Such organisation of the actin cytoskeleton in $P$. nudum was similar to that previously described in, e.g. G. verrucosa (van Lammeren et al. 1989), S. melongena (Traas et al. 1989), Zea mays (Staiger and Cande 1991) and M. soulangeana (Dinis and Mesquita 1993).

Two classes of MF were present in young meiocytes before division and in prophase I. Cortical MFs were located under the plasma membrane and central MFs were visible deeper in the cytoplasm and surrounded in a net-like manner the cell organelles dispersed in the cytoplasm. Both the cortical and central cytoplasmic filaments around the organelles persisted throughout cell division but in variable proportions and the central cytoplasmic network generally displayed different behaviour and higher dynamics of changes than the cortical network. In late prophase I, the number of MFs surrounding the cell organelles gradually decreased, which was accompanied by occurrence of perinuclear filament concentration (see also van Lammeren et al. 1989; Dinis and Mesquita 1993). It is probable that the nuclear region was the centre of microfilament organisation of the formed kariokinetic spindle.

In metaphase I and II, the MF formed an abundant network around the cell organelles dispersed in the cytoplasm and constituted part of the kariokinetic spindle extending from pole to pole in metaphase I and two spindles in a perpendicular orientation to each other in metaphase II. Such configurations of the actin cytoskeleton were also observed in meiocytes of other plants (van Lammeren et al. 1989; Traas et al. 1989; Bednara et al. 1990; Staiger and Cande 1991; Dinis and Mesquita 1993).

Next, during telophase I and II the phragmoplast appeared simultaneously with aggregation of plastids and mitochondria into the equatorial plane, which separated the daughter nuclei of the meiocyte. The phragmoplast microfilaments were placed parallel to the internuclear axis, which strongly suggests participation of these filaments in transport of material into the equatorial plate of organelles. The formation of the equatorial plate of the cell organelles in telophase I and II as well as changes in the cytoplasm during sporogenesis with simultaneous cytokinesis in $P$. nudum was described previously (Gabarajewa 1984a, b, 1985; Tchórzewska et al. 1996). Such a structure occurs in other plants with sporogenesis and microsporogenesis of the simultaneous type (Mann 1924; Lewitsky 1926; Jungers 1934; Wolniak 1967; Sheffield and Bell 1979; Brown and Lemmon 1987a, b, 1988a, 1991a, 2001b; Bednara and Rodkiewicz 1985; Bednara et al. 1986; Furness et al. 2002).

The most prominent information was provided by observation at the early telophase I where we observed microfilaments forming a phragmoplast, which disappeared relatively fast. This is probably related to the fact that in $P$. nudum sporogenesis proceeds with simultaneous cytokinesis and no primary wall is formed after meiotic division I. In late telophase I, MFs were visible mainly at the daughter nuclei (see 9a of Fig. 2) and formed a network throughout the cytoplasm (see 10b of Fig. 2). This observation provides significant supplementary information about MFs behaviour, which has been suggested before in $M$. soulangeana (Dinis and Mesquita 1993) and Solanum sp. (Genualdo et al. 1998). Additionally, we observed in our study that a short-lived phragmoplast in early telophase I composed of MF was located just under the plasma membrane, exactly at the site of formation of the future cell wall. These results support the hypothesis that, irrespective of the transport function, the actin phragmoplast in early telophase I marks the future division plane (Traas et al. 1989) just as the preprophase band does in mitotically dividing cells (Wick 1991).

The literature data about the cytoskeleton in dividing cells provide substantial information about the changes in configuration and the role of the tubulin cytoskeleton; however, there are only few reports of the actin cytoskeleton and even fewer about its role in meiosis. Therefore, to provide more data about the actin cytoskeleton, P. nudum sporocytes were treated with cytochalasin-B and the effect of MFs damage on the meiosis course during sporogenesis was assessed. Cytochalasin-B is an inhibitor which has high affinity to F-actin. It blocks lengthening and causes degradation of the existing microfilaments (Brown and 
Spudich 1979; Hartwig and Stossel 1979; Maruyama et al. 1980). In $P$. nudum sporocytes treated with cytochalasin-B, we observed only small, thick, and short fragments of MFs. Degradation of the actin cytoskeleton occurred in the kariokinetic spindle, the phragmoplast, and the cortical and central cytoplasmic network. Similar degradation was reported in angiosperm plant cells (Dinis and Mesquita 1993; Foissner and Wasteneys 1997, 2000). Besides, in cytochalasin-treated $P$. nudum cells, the daughter nuclei were located abnormally close to each other, the equatorial cell organelle aggregations was not formed and as a result of all the above-mentioned changes, meiosis did not proceed correctly. These results suggest that, irrespective of the tubulin cytoskeleton, the actin cytoskeleton plays a very important role in the cytoplasm organisation and formation of the cell wall.

In summary, the well-developed actin cytoskeleton, dynamic changes in MFs and the characteristic phragmoplast in early telophase I may suggest that MFs constitute an important element of the cell cytoskeleton in the plant cell during meiosis. Our data also indicate that if the actin cytoskeleton is destroyed, the meiosis is disturbed and, consequently, it may hamper formation of the functional spores.

Conflict of interest The authors declare that they have no conflict of interest.

Open Access This article is distributed under the terms of the Creative Commons Attribution Noncommercial License which permits any noncommercial use, distribution, and reproduction in any medium, provided the original author(s) and source are credited.

\section{References}

Baluska F, Barlow PW (1993) The role of the microtubular cytoskeleton in determining nuclear chromatin structure and passage of maize root cells through the cell cycle. Eur J Cell Biol 61:160-167

Battey NH, James NC, Greenland AJ, Brownlec C (1999) Exocytosis and endocytosis. Plant Cell 11:643-660

Bednara J, Rodkiewicz B (1985) Distribution of plastids and mitochondria during sporogenesis in Equisetum hyemale. In: Willemse MTM, van Went JL (eds) Sexual reproduction in seed plants, ferns and mosses. Pudoc, Wageningen, pp 17-19

Bednara J, Giełwanowska I, Rodkiewicz B (1986) Regular arrangements of mitochondria and plastids during sporogenesis in Equisetum. Protoplasma 130:145-152

Bednara J, Willemse MTM, van Lammeren AAM (1990) Organization of the actin cytoskeleton during megasporogenesis in Gasteria verrucosa visualized with fluorescent-labelled phalloidin. Acta Bot Neerl 39(1):43-48

Bednara J, Rodkiewicz B, Szczuka E (1995) The cytoskeleton organelles and rudimentary cytokinesis $\mathrm{I}$ in the sporogenesis of simultaneous type in Equisetum, Nymphaea and Delphinium. Plant Reproductive Biology, pp 9-16

Bershadsky AD, Vasiliev JM (1988) In: Cytoskeleton P, Siekievitz H (eds) Series on cellular organelles. Plenum Press, New York

Bierhorst DW (1971) Morphology of vascular plants. Macmillan, New York, pp 153-192

Bierhorst DW (1977) The systematic position of Psilotum and Tmesipteris. Brittonia 29:3-13

Bohdanowicz J, Szczuka E, Świerczyńska J, Sobieska J, KościńskaPająk M (2005) Distribution of microtubules during regular and disturbed microsporogenesis and pollen grain development in Gagea lutea. Acta Biol Crac Ser Bot 42(2):89-96

Brown RC, Lemmon BE (1982a) Ultrastructural aspect of moss meiosis: cytokinesis and organelle apportionment in Rhynchostegium serrulatum. Jour Hattori Bot Lab 53:41-50

Brown RC, Lemmon BE (1982b) Ultrastructure of meiosis in the moss Rhynchostegium serrulatum. I. Prophasic microtubules and spindle dynamics. Protoplasma 110:23-33

Brown RC, Lemmon BE (1985) A cytoskeletal system predicts division plane in meiosis of Selaginella. Protoplasma 127:101-109

Brown RC, Lemmon BE (1987a) Division polarity, development and configuration of microtubule arrays in Bryophyte meiosis. I. Meiotic prophase and metaphase I. Protoplasma 137:84-99

Brown RC, Lemmon BE (1987b) Division polarity, development and configuration of microtubule arrays in Bryophyte meiosis. II. Anaphase I to the tetrad. Protoplasma 138:1-10

Brown RC, Lemmon BE (1988a) Sporogenesis in bryophytes. Adv Bryology 3:159-223

Brown RC, Lemmon BE (1988b) Cytokinesis occurs at boundaries of domains delimited by nuclear-based microtubules in sporocytes of Conocephalum conicum (Bryophyta). Cell Motil Cytoskeleton 11:139-146

Brown RC, Lemmon BE (1991a) Plastid polarity and meiotic spindle development in microsporogenesis of Selaginella. Protoplasma 161:168-180

Brown RC, Lemmon BE (1991b) Pollen development in orchids. 1. Cytoskleleton and the control of division plane in irregular patterns of cytokinesis. Protoplasma 163:9-18

Brown RC, Lemmon BE (1991c) Pollen development in orchids. 2. The cytokinetic apparatus in simultaneous cytokinesis. Protoplasma 165:155-166

Brown RC, Lemmon BE (1996) Nuclear cytoplasmic domains, microtubules and organelles in microsporocytes of the slipper orchid Cypripedium californicum A. Gray dividing by simultaneous cytokinesis. Sex Plant Reprod 9:145-152

Brown RC, Lemmon BE (1998) Division polarity and plasticity of the meiosis I spindle in Cypropedium californicum (Orchidaceae). Protoplasma 203:168-174

Brown RC, Lemmon BE (2001a) Sporogenesis in eusporangiate ferns: I. Monoplastidic meiosis in Angiopteris (Marattiales). J Plant Res 114:223-235

Brown RC, Lemmon BE (2001b) Sporogenesis in eusporangiate ferns: II. Polyplastidic meiosis in Ophioglossum (Ophioglossales). J Plant Res 114:237-246

Brown RC, Lemmon BE (2004) $\gamma$-Tubulin, microtubule arrays, and quadripolarity during sporogenesis in the hepatic Aneura pinguis (L.) Dumort. (Metzgeriales). J Plant Res 117:371-376

Brown RC, Lemmon BE (2009) Pre-meiotic bands and novel meiotic spindle ontogeny in quadrilobed sporocytes of leafy liverworts (Jungermannidae, Bryophyta). Protoplasma 237:41-49

Brown SS, Spudich JA (1979) Cytochalasin inhibits the rate of elongation of actin filament fragments. J Cell Biol 83:657-662

Dinis AM, Mesquita JF (1993) The F-actin distribution during microsporogenesis in Magnolia soulangeana Soul. (Magnoliaceae). Sex Plant Reprod 6:57-63

Dustin P (1984) Microtubules, 2nd edn. Springer, Berlin 
Foissner L, Wasteneys GO (1997) A cytochalasin-sensitive actin filament meshwork is a prerequisite for local wound wall deposition in Nitella internodal cells. Protoplasma 200:17-30

Foissner L, Wasteneys GO (2000) Microtubule disassembly enhances reversible cytochalasin-dependent disruption of actin bundles in characean internodes. Protoplasma 214:33-44

Fosket DE (1989) Cytoskeletal proteins and their genes in higher plants. Biochem Plants 15:393-453

Furness CA, Rudall PJ, Samson FB (2002) Evolution of microsporogenesis in angiosperms. Int J Plant Sci 163:235-260

Gabarajewa NI (1984a) Razvitie spor u Psilotum nudum (Psilotaceae): izmienienija citoplazmy i kljetocznych organell w predmiejoticzieskoj interfazie-leptoten. Bot Zhur 69(11):1441-1450

Gabarajewa NI (1984b) Razvitie spor u Psilotum nudum (Psilotaceae): izmienienija citoplazmy i kljetocznych organell w zigoteniepachitenie. Bot Zhur 69(12):1612-1622

Gabarajewa NI (1985) The development of spores in Psilotum nudum (Psilotaceae): changes in cytoplasm and organelles of spore mother cells in metaphase and telophase I of meiosis. Bot Zhur 70(4):441-450

Genualdo G, Errico A, Tiezzi A, Conicella C (1998) $\alpha$-Tubulin and Factin distribution during microsporogenesis in a $2 \mathrm{n}$ pollen producer of Solanum. Natl Res Counc Can 41(5):636-641

Gunning BES (1981) Microtubules and cytomorphogenesis in a developing organ: the root primordium of Azolla pinnata. In: Kiermayer O (ed) Cytomorphogenesis in plants. Springer, Wien, Alfert M et al (eds) Cell biology monographs, vol 8, pp 302-324

Gunning BES, Hardham AR (1982) Microtubules. Annu Rev Plant Physiol 33:651-698

Hartwig JH, Stossel TP (1979) Cytochalasin B and the structure of actin gels. J Mol Biol 134:539-553

Hasebe M, Wolf PG, Pryer KM, Ueda K, Ito M, Sano R, Gastony GJ, Yokoyama J, Manhart JR, Murakami N, Crane EH, Haufler CH, Hauk WD (1995) Fern phylogeny based on $r b c L$ nucleotide sequences. Am Fern J 85:134-181

Hepler PK (1981) Morphogenesis of tracheary elements and guard cells. In: Kiermayer $\mathrm{O}$ (ed) Cytomorphogenesis in plants. Springer, Wien, Alfert $\mathrm{M}$ et al (eds) Cell biology monographs, vol 8,pp 327-347

Hepler PK, Cleary AL, Gunning BES, Wadsworth P, Wasteneys GO, Zhang DH (1993) Cytoskeletal dynamics in living plant cells. Cell Biol Intern 17(2):127-142

Jungers V (1934) Mitochondries, chromosomes et fuseau dans les sporocytes de 1'Equisetum limosum. Cellule 43:321-340

van Lammeren AAM, Bednara J, Willemse MTM (1989) Organization of the actin cytoskeleton during pollen development in Gasteria verrucosa (Mill.) H. Duval. visualized with rhodaminephalloidin. Planta 178:531-539

Lewitsky G (1926) Die chondriosomen in der Gonogenese bei Equisetum palustre L. Planta 1:301-316

Lloyd CW, Seagull RW (1985) A new spring for plant cell biology: microtubules as dynamic helices. Trends Biochem Sci 10:476-478

Manhart JR (1994) Phylogenetic analysis of green plant $r b c L$ sequences. Mol Phylogenet Evol 3:114-127

Manhart JR (1995) Chloroplast 16S rDNA sequences and phylogenetic relationships of fern allies and ferns. Am Fern J 85:182-192

Mann MC (1924) Microsporogenesis of Ginkgo biloba L. with especial reference to the distribution of the plastids and to cell wall formation. Univ Calif Publ Agric Sc 2:243-248

Maruyama K, Hartwig JH, Stossel TP (1980) Cytochalasin B and the structure of actin gels. II. Further evidence for the splitting of Factin by cytochalasin B. Biochem Biophys Acta 626:494-500
Nickrent DL, Parkinson CL, Palmer JD, Duff RJ (2000) Multigene phylogeny of land plants with special reference to bryophytes and the earliest land plants. Mol Biol Evol 17:1885-1895

Pahnke J, Goremykin V, Bobrova V, Troitsky A, Antonov A, Martin W (1996) Utility of rDNA internal transcribed spacer sequences from the inverted repeat of chloroplast DNA in pteridophyte molecular phylogenetics. In: Camus JM, Gibby M, Johns RJ (eds) Pteridology in perspective. Royal Botanical Gardens, Kew, pp 217-230

Pryer KM, Smith AR, Skog JE (1995) Phylogenetic relationships of extant ferens based on evidence from morphology and rbcL sequences. Am Fern J 85:205-282

Pryer KM, Schneider H, Smith AR, Cranfill R, Wolf PG, Hunt JS, Sipes SD (2001) Horsetails and ferns are a monophyletic group and the closest living relatives to seed plants. Nature 409:618-622

Renzaglia KS, Johnson TH, Gates HD, Whittier DN (2001) Architecture of the sperm cell of Psilotum. Am J Bot 88(7):1151-1163

Renzaglia KS, Schuette S, Duff RJ, Ligrone R, Shaw AJ, Mishler BD, Duckett JG (2007) Bryophyte phylogeny: advancing the molecular and morphological frontiers. Bryologist 110(2):179-213

Rothwell GW (1999) Fossils and ferns in the resolution of land plant phylogeny. Bot Rev 65:188-218

Sheffield E, Bell PR (1979) Ultrastructural aspects of sporogenesis in fern Pteridium aqualinum (L.) Kuhn. Ann Bot 44:392-405

Staiger CJ, Cande WZ (1991) Microtubule distribution in $d v$, a maize meiotic mutant defective in the prophase to metaphase transition. Dev Biol 139:231-242

Staiger CJ, Cande WZ (1993) Cytoskeletal analysis of maize meiotic mutants. In: Molecular and cell biology of the plant cell cycle. Academic Publishers, Dordrecht, pp 157-171

Tchórzewska D, Brukhin VB, Bednara J (1996) Plastids and mitochondria comportment in dividing meiocytes of Psilotum nudum. Acta Soc Bot Pol 65(1-2):91-96

Tchórzewska D, Winiarczyk K, Pietrusiewicz J, Bednara J (2008) A new type of microtubular cytoskeleton in microsporogenesis of Lavatera thuringiaca L. Protoplasma 232:223-231

Traas JA, Burgain S, Dumas de Vaulx R (1989) The organization of the cytoskeleton during meiosis in eggplant (Solanum melongena L.): microtubules and $\mathrm{F}$-actin are both necessary for coordinated meiotic division. J Cell Sci 92:541-550

Wagner WH (1977) Systematic implications of the Psilotaceae. Brittonia 29:54-63

White RA (1977) Taxonomic and morphological relationships of the Psilotaceae: introduction to the symposium and discussion. Brittonia 29(1-2):64-68

Wick SM (1991) Spatial aspects of cytokinesis in plant cells. Curr Opin Cell Biol 3:253-260

Wolf PG (1997) Evaluation of atpB nucleotide sequences for phylogenetic studies of ferns and other pteridophytes. Amer J Bot 84:1429-1440

Wolf PG, Pryer KM, Smith AR, Hasebe M (1998) Phylogenetic studies of extant pteridophytes. In: Soltis DE, Soltis PS, Doyle JJ (eds) Molecular systematic of plants. Kluwer, Boston, pp 540-556

Wolniak SM (1967) Organelle distribution and apportionment during meiosis in the microsporocyte of Ginkgo biloba L. Amer J Bot 63(2):251-258

Van GK, Kohler RH, Verbelen JP (2002) Plant mitochondria move on $\mathrm{F}$-actin, but their positioning in the cortical cytoplasm depends on both F-actin and microtubules. J Exp Bot 53:659-667

Zhao H-P, Liu A-X, Ren D-T, Liu G-Q, Yen L-F (1999) Identification of myosin on the surface of wheat mitochondria. Acta Bot Sin 41:1303-1306 